УДК 330.59

DOI: $10.15673 /$ fie.v11i4.1552

\author{
Седікова І.О. \\ доктор економічних наук, профресор \\ кафедра менеджменту та логістики \\ E-mail: irina-sedikova@ukr.net \\ ORCID ID: 0000-0003-4376-1267 \\ Дьяченко Ю.В. \\ кандидат економічних наук, доцент \\ кафедра менеджменту та логістики \\ Одеська національна академія харчових технологій \\ вул. Канатна, 112, м. Одеса, Україна, 65039 \\ E-mail: ypogarchuk@gmail.com \\ ORCID ID: 0000-0002-8754-3256
}

\title{
ШЛЯХИ ЗНИЖЕННЯ ПРОДОВОЛЬЧИХ ВТРАТ ТА ХАРЧОВИХ ВІДХОДІВ
}

У цьому дослідженні проаналізовано причини виникнення продовольчих втрат та харчових відходів у харчовому ланцюгу: від первинного виробництва до споживання. Встановлено, що продовольчі втрати та харчові відходи виникають на мікро-, мезо- та макрорівні. Причини мезо- та макрорівнів мають фізичний, технічний, поведінковий характер і породжуються соціально-економічними та інституціональними явищами. Продовольчі втрати та харчові відходи на макрорівні виникають на протязі всього шляху харчового ланцюга. Визначено коло потенційних рішень та суб'єктів, які беруть участь у реалізації зниження цих втрат, від фермерів до споживачів. Доведено, що рішення на мезорівні повинні базуватися на узгоджених та колективних зусиллях. Запропоновано шляхи зниження продовольчих втрат та харчових відходів на означених рівнях.

Ключові слова: харчові втрати, відходи, продовольча безпека, продукти харчування.

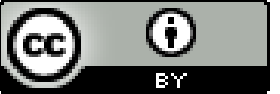

This work is licensed under a Creative Commons Attribution 4.0 International License http://creativecommons.org/licenses/by/4.0/
Постановка проблеми та її зв'язок з важливими науковими та практичними завданнями. Недоїдання, погіршення екологічної ситуації, скорочення природних ресурсів є головними проблемами світу. Зменшення обсягів продовольчих втрат та харчових відходів $\epsilon$ пріоритетним напрямом задля вирішення проблем голоду. Доступ до належної кількості безпечних продуктів харчування $є$ найважливішим чинником для підтримки життя і зміцнення здоров'я націй.

У вересні 2017 року Уряд України представив Національну доповідь «Цілі сталого розвитку: Україна», яка визначає базові показники для досягнення Цілей сталого розвитку: «...здійснення Десятирічної стратегії дій 3 переходу до використання раціональних моделей споживання і виробництва за участю всіх країн .... До 2030 року скоротити вдвічі в перерахунку на одну особу населення загальносвітовий обсяг харчових відходів на роздрібному та споживчому рівнях і зменшити втрати продовольства у виробничо-збутових ланцюгах, у тому числі післязбиральні втрати...» [13]. Отже, визначення шляхів скорочення продовольчих втрат та харчових відходів на сучасному етапі $є$ вкрай актуальним.

Аналіз останніх досліджень і публікацій. Проблемі зниження харчових відходів присвячені чисельні наукові праці вітчизняних та зарубіжних вчених, так у роботах російських вчених А. Голубєва, В. Варшавського розглядаються причини виникнення продовольчих втрат та харчових відходів, підкреслюється необхідність їх скорочення в інтересах підвищення продовольчої безпеки та стійкості продовольчих систем. Даний напрям широко досліджується вітчизняними авторами, зокрема, питання ефективного використання харчових відходів розглядається у працях В. Міщенка, Г. Виговської, В. Єрмоленка, Т. Омельяненка, Ю. Маковецької, І. Дрозд, В. Коломієць.

Зарубіжні науковці, G. Aiello, M. \& M. Enea у своїх працях проводять оцінку економічних вигод від відновлення продуктів харчування на етапі роздрібної торгівлі. А. Бернстад, Я. Кур, Дж. Аспегрен розглядають питання скорочення харчових відходів у секторі індустрії гостинності та громадського харчування. Зменшенню навантаження харчових відході на екосистему у глобальних продовольчих системах присвячені роботи М. Бонда, Т. Мичама, Р. Бхунну.

Дж. Бруинсма, А. Чапагайн досліджують перспективи використання природних ресурсів (землі, води, нафти) до 2050 року, аналізують вплив харчових відходів на водні ресурси та зміну клімату. Глобальні втрати продовольства та харчові відходи, їх 
масштаби, причини і запобігання висвітлені у працях Дж. Густавссона, К. Седерберга, У. Сонессона, Р. ван Оттердейка та А. Мейбек.

Формулювання цілей дослідження. Метою даного дослідження $є$ визначення шляхів зниження продовольчих втрат та харчових відходів, які виникають на всьому шляху харчового ланцюга.

Виклад основних результатів та їх обгрунтування. У 1996 р на Всесвітньому продовольчому саміті вперше було привернуто увагу світової спільноти на зростання числа голодуючих на планеті. Згідно 3 наведеними даними у доповіді «Стан справ в області продовольчої безпеки і харчування в світі» [1], у 2017 році кількість людей, що зіткнулися з про- блемою недоїдання склало 821 млн. чол. Проблема недоїдання, гострої відсутності продовольчої безпеки посилюється у Африці, Південній Америці, у той час як у більшості регіонів Азії ситуація щодо неповноцінного харчування залишається стабільною. Крім недоїдання, на сучасному етапі, до поглиблення проблеми веде проблема надлишкової ваги та ожиріння, що $\epsilon$ наслідком неповноцінного та неправильного харчування в багатьох країнах. У 2017 році від надмірної ваги страждали більше 38 мільйонів дітей у віці до п'яти років, причому на частку Африки та Азї̈ припало $25 \%$ та $46 \%$ відповідно [2]. Кількість людей $з$ надмірною масою тіла та ожиріння наведено у табл. 1.

Таблиця 1

Надмірна маса тіла, ожиріння*

\begin{tabular}{|c|c|c|}
\hline & Надмірна маса тіла & Ожиріння \\
\hline Світ & 1 млрд. & 300 млн. \\
\hline \multirow{3}{*}{ Європа } & 400 мЛн. & 130 млн. \\
\hline & $\begin{array}{c}\text { Чоловіки } \\
32 \%-72 \%\end{array}$ & $\begin{array}{l}\text { Чоловіки } \\
5 \%-23 \%\end{array}$ \\
\hline & $\begin{array}{c}\text { Жінки } \\
28 \%-78 \%\end{array}$ & $\begin{array}{c}\text { Жінки } \\
7 \%-30 \%\end{array}$ \\
\hline Діти (Свропа) & $17 \%-20 \%$ & 15 млн. \\
\hline
\end{tabular}

Серйозне занепокоєння викликає якість та безпека харчових продуктів та їх вплив на здоров'я людини. За даними Всесвітньої організації охорони здоров'я, небезпечні продукти харчування, що містять хвороботворні бактерії та канцерогенні речовини $\epsilon$ причиною більш ніж 200 захворювань, від онкології до діареї, що розвиваються в результаті вживання забруднених харчових продуктів, від яких щорічно захворює понад 0,5 млрд. чоловік, а 230 тис. помирають [3]. Ще однією проблемою, яка викликає занепокоєння світової спільноти є проблема світових продовольчих втрат та харчових відходів. FAO констатує, що у світі пропадає або викидається майже 1/3 всіх вироблених продуктів харчування $\approx 1,4$ млрд. т на рік. До продовольчих втрат можна віднести ту частину продуктів, яка втрачається у процесі вирощування, виробництва та обробки продуктів харчування (неїстівні частини, зіпсований урожай тощо), харчові відходи переважно створюють самі споживачі, викидаючи їжу, яка могла б бути використана та спожита. У країнах, що розвиваються, продовольчі втрати є значними, а кількість харчових відходів мінімальна, у розвинених країнах, із більш ефективним виробництвом, харчові відходи є досить значними, причиною чому є марнотратство та безпечність (див. рис. 1).
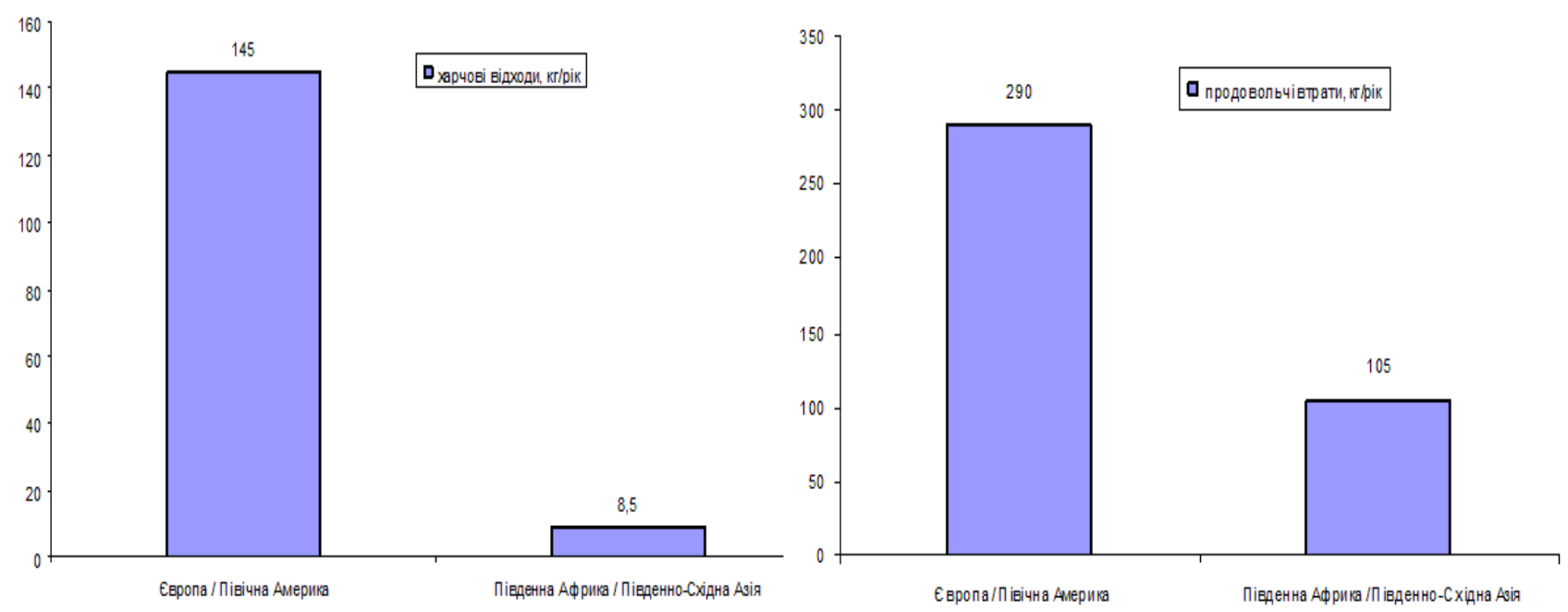

Рис. 1 - Середній рівень продовольчих втрат на душу населення у країнах світу

* авторська розробка 
Продовольчі втрати є одним із елементів функціонування продовольчих систем на технікотехнологічному, фінансово-економічному, соціальнокультурному рівнях. На нашу думку, зниження продовольчих втрат та харчових відходів $\epsilon$ пріоритетом у забезпеченні продовольчої безпеки та зниженні антропогенного навантаження продовольчих систем на навколишнє середовище.

Під продовольчими втратами і харчовими відходами розуміється скорочення обсягу продовольства, призначеного для вживання в їжу людиною, на всіх етапах продовольчого ланцюга від збору врожаю до етапу споживання в масі, незалежно від причин, які їх викликають [4]. Під харчовими відходами розуміється продовольство, призначене для вживання в їжу людиною, яка викидається або псується на етапі споживання - незалежно від причин [5]. Аналіз причин виникнення харчових виробничих відходів у продовольчому ланцюгу дав змогу дістатися висновку, що причини, які їх викликають, взаємопов'язані та залежать від характеру продукції та місцевих умов. Надалі розглянемо можливі рішення скорочення продовольчих втрат та харчових відходів на різнях етапах їх виникнення, а саме індивідуальні, технічні, поведінкові, інноваційні.

Для зниження існуючих проблем на етапі виробничо-збутового ланцюга потрібно прийняття індивідуальних, технічних та поведінкових рішень. Дані рішення повинні враховувати інноваційноінвестиційний досвід, зміну поведінки. Розв'язання проблеми на стадії виробництва та споживання мусять включати результати новітніх розробок та технологій у сільському господарстві, Застосування нового обладнання на етапі зберігання продукції, впровадження е-технологій на етапі транспортування, переробки та пакування. Вектор розв'язання цих проблем лежить у площині зменшення відходів при споживанні, охоплюють заходи в секторі громадського харчування та домогосподарств.

В аграрній галузі є багатий діапазон інноваційних розробок у кожному секторі (землеробстві, тваринництві, рослинництво тощо). В Україні широко використовуються ноу-хау при обробці грунту для підвищення його родючості. Однак, крім позитивних результатів існують негативні, які відображаються у забруднені грунтових вод та зниженні рівня поживних речовин та організмів [6].

Більшість продовольчих втрат та харчових відходів відбувається при зберіганні та транспортуванні продукції. Поліпшення умов зберігання $є$ підгрунтям для впровадження нових умов на всіх рівнях продовольчого ланцюга. Серед таких слід виділити технологію герметичного зберігання SiloBag. Герметична система виправдовує принцип - зберігання зерна сухим в зміненій атмосфері, 3 низьким вмістом кисню і високою концентрацією вуглекислого газу [7].

Слід зазначити, що майже у всіх галузях виробництва харчової продукції є технологічні процеси (продукти), що потребують певного температурного режиму виробництва, зберігання, транспортування при порушенні якого продукція безповоротно втрачає якість та придатність. «Фреш-логістика» $є$ незамінною частиною на сучасному висококонкурентному ринку швидкопсувних товарів 3 коротким терміном зберігання, оскільки, контролюючи «холодний ланцюг поставок», є можливість якнайкраще та якнайповніше задовольнити потреби кінцевих споживачів у якісному і свіжому продукті. [8,9].

Наступною причиною продовольчих втрат та псування продукції $є$ неякісна упаковка. Майбутній напрям розвитку галузі пакування, на погляд автора, повинен враховувати такі фактори, як глобалізація ринків; зростання чисельності населення; екологічні та кліматичні зміни; спосіб життя; зручність; відповідність часу та прогнозування майбутнього; демографію; урбанізацію. [10, 11].

Вагомий вклад у сумарні продовольчі втрати вносить індустрія гостинності (кафе, бари, ресторани, кейтеринг). У даній галузі кожного року викидається на сміття мільйон тон харчів (70 \% якого могло було застосувати у їжу). Лю в своєму дослідженні [12] вказує, що першим етапом у скорочені харчових відходів $\epsilon$ «вимір, обсяги, типи та причини їх виникнення. Це $\epsilon$ підгрунтям для розробки стратегії зменшення харчових відходів у ресторанному бізнесі». Проведені дослідження та узагальнені дані свідчать про ефективність програм боротьби з харчовими відходами та їх зниження. Яскравим прикладом є столові та кейтерінг. Досвід обслуговування без підносів у США дозволив знизити харчові відходи на $19 \%$, а рідких відходів на $6 \%$.

В Об'єднаних Арабських Еміратах ресторатори запровадили новий сервіс, пропонуючи гостям отримати їжу не класичними порціями, а на вагу.

Фудшерінг - це рух 3 порятунку їі, метою якого $є$ зменшення утилізації невикористаної їжі. Люди діляться їжею через соціальні мережі, а також у спеціально відведених місцях. На нашу думку, зменшенню харчових відходів, по-перше, сприятиме створення умов за яких виробники відходів будуть зацікавлені в їх мінімізації доведення знань про можливість отримання додаткової вигоди. По-друге, потрібно провести маркетингові дослідження 3 вторинного використання харчових відходів, їх сортування та переробки. Прикладом може слугувати готельноресторанний комплекс «Одеса» (м. Одеса, Україна), який розпочав сортувати відходів та реалізацію на своєму власному фермерському господарстві. Групи харчових відходів, що утворюються у готельноресторанному комплексі наведено у табл. 2.

Таблиця 2

Групи харчових відходів, що утворюються у готельно-ресторанному комплексі «Одеса»*

\begin{tabular}{|l|l|l|}
\hline \multicolumn{2}{|c|}{ Групи відходів } \\
\hline \multicolumn{1}{|c|}{ рідкі } & \multicolumn{1}{|c|}{ м'які } & \multicolumn{1}{|c|}{ тверді } \\
\hline \begin{tabular}{l}
\multicolumn{1}{|c|}{ залишки перших страв, фруктових } \\
напоїв, соків тощо.
\end{tabular} & $\begin{array}{l}\text { залишки других страв, салатів, м'ясних } \\
\text { страв, мезга, овочеві очистки тощо. }\end{array}$ & $\begin{array}{l}\text { залишки кісточкових фруктів, } \\
\text { кістки, тара (картонна, пласт- } \\
\text { масова, скляна) тощо. }\end{array}$ \\
\hline
\end{tabular}

* авторська розробка 
3 метою мінімізації усіх видів відходів запропоновано сортування сміття; організація обслуго- вування мініферми. Обгрунтування даного проекту наведено у табл. 3.

Таблиця 3

Обгрунтування доцільності проекту*

\begin{tabular}{|l|c|c|}
\hline \multirow{2}{*}{ Статті витрат, тис. грн. } & \multicolumn{2}{|c|}{ Значення показника за строк реалізації проекту } \\
\cline { 2 - 3 } & 2020 & 2101,10 \\
\hline Виручка від реалізації & 2236,40 & 2049,85 \\
\hline Поточні витрати, у т.ч. & 2181,85 & 246,1 \\
\hline витрати на вирощування & 246,1 & 1776,25 \\
\hline витрати на купівлю поросят & 132 & 7,1 \\
\hline витрати на корми & 1776,25 & 6,3 \\
\hline витрати на ветпрепарати & 7,1 & 10 \\
\hline вартість підстилки & 6,3 & 4,1 \\
\hline Вартість поїлки & 5 & 0 \\
\hline Ланцюг з скребками (для вбирання) & 10 & 16,8 \\
\hline вартість, води & 4,1 & 51,25 \\
\hline вартість ангара & 70 & 9,22 \\
\hline Амортизаційні відрахування & 16,8 & 42,02 \\
\hline Оподаткований прибуток & 54,55 & 58,82 \\
\hline Податок на прибуток & 9,82 & 0,5739 \\
\hline Чистий прибуток & 44,73 & 33,76 \\
\hline Чисті грошові надходження & 61,53 & 80,37 \\
\hline Коефіцієнт дисконтування & 0,7576 & \\
\hline Чистий приведеній дохід & 46,61 & \\
\hline Чистий приведений дохід накопиченим & 46,61 & \\
підсумком & & \\
\hline
\end{tabular}

* авторська розробка

Показники інвестиційної привабливості проекту свідчать про його економічну ефективність, так:
1. Чиста приведена вартість проекту (Net Present Value, NPV) більше нуля.

$$
N P V=\sum_{t}^{n} \frac{C F_{t}}{(1+r)^{t}}=10,37 \text { тис. грн. }
$$

де

$\mathrm{n}, \mathrm{t}$ - кількість часових періодів,

CF - грошові надходження (Cash Flow), $\mathrm{r}$ - ставка дисконтуванння (Rate)

2. Індекс прибутковості PI (Profitability Index):

$$
P I=\frac{\sum_{t=1}^{n} \frac{B_{i}}{(1+r)^{i}}}{I_{0}}=1,15
$$

де

Вi - грошові надходження даного періоду,

$\mathrm{r}$ - ставка дисконтування,
$\mathrm{I}_{0}$ - стартові інвестиції,

$\mathrm{n}$ - термін реалізації проекту..

3. Строк окупності інвестицій.

$$
D P P=\frac{I_{0}}{\sum_{t=1}^{n} \frac{C F_{t}}{(1+r)^{t}}} 1,74
$$

де:

n - кількість років життя проекту;

$\mathrm{CF}_{\mathrm{t}}$ - середньорічний чистий приведений дохід від реалізації проекту;

$\mathrm{r}$ - коефіцієнт дисконтування;

$\mathrm{I}_{\mathrm{o}}$ - витрати на реалізацію інвестиційного проекту.

Після реалізації проекту готельноресторанний комплекс отримує збільшення доходу в
1,72 рази. Показники інвестиційної привабливості свідчать про економічну доцільність реалізації даного проекту.

Висновки та напрями подальших досліджень. У країнах, що розвиваються, покращення ситуації полягає у вдосконаленні виробництва, інвестуванні в інфраструктуру харчової промисловості, вдосконалення технічного обладнання та навичок людей, що відповідають за обробку та зберігання продоволь- 
ства.

У розвинених країнах найефективніші стратегії включають покращення комунікації між виробниками і торгівцями, для уникнення перевиробництва, удосконалення системи маркування продуктів. А, також, достатнє інформування виробників та споживачів про економічні та екологічні наслідки харчових відходів, і про способи їх зменшення.

Запропоновано інноваційний проект 3 вторинного використання харчових відходів, їх сортування та переробки, на прикладі готельно- ресторанного комплексу «Одеса», який розпочав сортувати відходів та реалізацію на своєму власному фермерському господарстві. Розраховані показники інвестиційної привабливості свідчать про економічну доцільність реалізації даного проекту.

Сучасні підходи та технології дають змогу збільшить діапазон використання харчових відходів. Подальші дослідження варто проводити у площині пошуків напрямів їх використання як вторинної сировини та розвитку інструментів їх практичної реалізації як на макро-, міко- та мезорівнях.

\section{Література}

1. Стан справ в області продовольчої безпеки і харчування в світі 2018 // FAO. Женева, 2018. URL: https://reliefweb.int/sites/reliefweb.int/files/resources (дата звернення: 2.10.2019).

2. У світі понад 41 млн. дітей до п'яти років страждають на ожиріння - ВООЗ // ВООЗ. Женева, 2017. URL: https://www.unian.ua/ (дата звернення: 05.10.2019).

3. Інформаційний бюлетень // ВООЗ. Женева, 2017. URL: https://apps.who.int/mediacentre (дата звернення: 06.10.2019).

4. Tefera T. K., Kanampiu F. D., De Groote H. G. The metal silo: an effective grain storage technology for reducing post-harvest insect and pathogen losses in maize while improving smallholder farmers' food security in developing countries // Crop Protection. 2015. Vol. 3, No. 30. P. 240-245. doi: 10.1016/j.cropro.2010.11.015

5. Appropriate food packaging solutions for developing countries. // FAO. Rome, 2018. URL: http://www.fao.org/docrep/015/mb061e/mb061e00.pdf (дата звернення: 9.10.2019).

6. Foscaches C., Sproesser R., Quevedo-silva F. Logística de frutas, legumes e verduras (FLV): um estudo sobre embalagem, armazenamento e transporte em pequenas cidades brasileiras // Informações Econômicas. 2012. Vol. 42, No. 2. P. 11-18.

7. Отвальный плуг, Mini-Till, No-Till. Плюсы и минусы трех технологий - какая технология перспективней? // Журнал «Зерно». Київ, 2019. URL: http://agro.upec.ua/articles/detail.php (дата звернення: 2.10.2019).

8. Getlinger M., Laughlin V., Bell E. Food waste is reduced when elementary-school children have recess before lunch // Am. Diet Assoc. 2016. Vol. 96, No. 9. P. 906-908. doi: 10.1016/S0002-8223(96)00245-3

9. Whitehair K., Shanklin C., Brannon L. Written messages improve edible food waste behaviors in a university dining facility // Acad. Nutr. Diet. 2013. Vol. 113, No. 4. P. 63-69. . doi: 10.1016/j.jand.2012.09.015

10. Evans D. Beyond the throwaway society: ordinary domestic practice and a sociological approach to household food waste // Sociology. 2018. Vol. 21, No. 4. P. 429-440.

1. 11. Li X., Poon C., Chung S. Waste reduction and recycling strategies for the in-flight services in the airline industry // Resources, Conservation and Recycling . 2016. Vol. 37, No. 1. P. 87-99. doi: doi.org/10.1016/j.resconrec.2016.03.023

12. Liu G. Food losses and food waste in China: a first estimate // OECD Food, Agriculture and Fisheries Papers. 2017. Vol. 66, No. 7. P. 47-55.

13. Цілі сталого розвитку 2016-2030 // united Nations Ukraine. Женева, 2017. URL: http://www.un.org.ua/ua/tsili-rozvytku-tysiacholittia/tsili-staloho-rozvytkuundefined (дата звернення: 9.10.2019).

Седикова И.А.

доктор экономических наук, профессор

E-mail: irina-sedikova@ukr.net

ORCID ID: 0000-0003-4376-1267

Дьяченко Ю.В.

кандидат экономических наук, доцент

кафредра менеджмента и логистики

Одесская национальная академия пищевых технологий

ул. Канатная, 112, г. Одесса, Украина, 65039

E-mail: ypogarchuk@gmail.com

ORCID ID: 0000-0002-8754-3256

\section{ПУТИ СНИЖЕНИЯ ПРОДОВОЛЬСТВЕННЫХ ПОТЕРЬ И ПИЩЕВЫХ ОТХОДОВ}

Недоедания, ухудшение экологической ситуации, сокращение природных ресурсов в мире являются главными проблемами мира. Уменьшение объемов пищевых потерь и отходов является 
приоритетным направлением для решения указанных проблем. В статье дано определение продовольственных потерь и пищевых отходов, рассмотрен вопрос влияния продовольственных потерь и пищевых отходов на устойчивость продовольственных систем и их способность обеспечивать продовольственную безопасность.

Проведен анализ причин возникновения пищевых отходов на пути от производителя до потребителя, при разной организации производства, хранения, переработки, каналов сбыта и дистрибуции, с целью выявления взаимосвязи между причинами, возникающими на разных уровнях (структурном и системном). Причины мезо и макроуровней имеют фризический, технический, поведенческий характер и порождаются экономическими, социальными и институциональными явлениями. Продовольственные потери и отходы на макроуровне возникают на всем этапе пищевой цепи. Определен круг потенциальных решений и субъектов, участвующих в реализации снижения этих потерь, от фермеров до потребителей. Доказано, что решения на мезоуровне должны базироваться на согласованных и коллективных действиях. Предложены пути снижения продовольственных потерь и отходов на указанных уровнях.

Предложено инновационный проект по вторичному использованию пищевых отходов, их сортировки и переработки на примере гостинично-ресторанного комплекса «Одесса», который начал сортировать отходов и реализацию на своем собственном фермерском хозяйстве. Рассчитанные показатели инвестиционной привлекательности свидетельствуют об экономической целесообразности реализации данного проекта.

Ключевые слова: пищевые потери, отходы, продовольственная безопасность, продукты питания.

\author{
Sedikova I. \\ Doctor of Economics, Professor \\ Department of Management and Logistics \\ E-mail: irina-sedikova@ukr.net \\ ORCID ID: 0000-0003-4376-1267 \\ Diachenko Yu. \\ Ph.D., Assistant \\ Department of Management and Logistics \\ Odessa National Academy of Food Technologies \\ Kanatna str., 112, Odesa, Ukraine, 65039 \\ E-mail: ypogarchuk@gmail.com \\ ORCID ID: 0000-0002-8754-3256
}

\title{
WAYS TO REDUCE FOOD LOSES AND FOOD WASTE
}

Malnutrition, environmental degradation, and reduction of natural resources in the world are major problems of the world. Reducing food waste and loses is a priority to deal with these issues. Access to the right amount of safe food is paramount to sustaining life and promoting the health of nations.

Another problem that is of concern to the world community is the problem of global food losses and food waste. The FAO states that almost $1 / 3$ of all food produced is lost or disposed of in the world -1.4 billion tons per year. Food losses include those products that are lost in the process of growing, producing and food processing (inedible parts, spoiled crops, etc.). Nevertheless, food waste is mostly created by consumers themselves, throwing away food that could be used and consumed.

Food loss is one element of the food systems functioning at the technological, financial, economic, socio-cultural levels. In our view, the reduction of food waste is a priority in ensuring food security and reducing the anthropogenic burden of food systems on the environment.

Food losses and food waste mean the reduction of food intended for human consumption at all stages of the food chain from harvest to mass consumption, regardless of the reasons that cause them.

The analysis of the causes of food production waste in the food chain, from primary production to consumption, concludes that the causes are related to each other and depend on the nature of the production and local conditions.

The analysis of the food waste causes from a producer to a consumer, with different organization of production, storage, processing, distribution and distribution channels, is carried out in order to identify the relationship between the causes that arise at different levels (structural and systemic). The causes of the meso- and macro- levels are physical, technical, behavioral in nature and generated by economic, social and institutional phenomena. Macro-level food losses and waste occur throughout the food chain. The circle of potential solutions and actors involved in implementing the reduction of these losses, from farmers to consumers, has been identified. It has been proved that decisions at the meso-level should be based on coordinated and collective actions. Ways to reduce food losses and waste at these levels have been proposed. 
An innovative project has been proposed for the recycling of food waste, its sorting and processing, using the hotel and restaurant complex Odessa as an example, which began sorting waste and selling it on its own farm. The calculated indicators of investment attractiveness indicate the economic feasibility of implementing this project.

Keywords: food losses, waste, food security, food.

\section{References}

1. Stan sprav v oblasti prodovolchoi bezpeky i kharchuvannia v sviti 2018. (2018). Retrieved October 2, 2019, from https://reliefweb.int/sites/reliefweb.int/files/resources .

2. U sviti ponad $41 \mathrm{mln}$. ditei do piaty rokiv strazhdaiut na ozhyrinnia - VOOZ. (2017). Retrieved October 5, 2019, from https://www.unian.ua/.

3. Informatsiinyi biuleten. (2017). Retrieved October 6, 2019, from https://apps.who.int/mediacentre.

4. Tefera, T. K., Kanampiu, F. D., \& De Groote , H. G. (2015). The metal silo: an effective grain storage technology for reducing post-harvest insect and pathogen losses in maize while improving smallholder farmers' food security in developing countries. Crop Protection, 3(30), 240-245. doi: 10.1016/j.cropro.2010.11.015

5. Appropriate food packaging solutions for developing countries. (2018). Retrieved October 9, 2019, from http://www.fao.org/docrep/015/mb061e/mb061e00.pdf.

6. Foscaches, C., Sproesser, R., \& Quevedo-silva, F. (2012). Logística de frutas, legumes e verduras (FLV): um estudo sobre embalagem, armazenamento e transporte em pequenas cidades brasileiras. Informações Econômicas, 42(2), 11-18.

7. Otvalnyiy plug, Mini-Till, No-Till. Plyusyi i minusyi treh tehnologiy - kakaya tehnologiya perspektivney. (2019). Zerno. Retrieved from http://agro.upec.ua/articles/detail.php

8. Getlinger, M., Laughlin, V., \& Bell, E. (2016). Food waste is reduced when elementary-school children have recess before lunch. Am. Diet Assoc, 96(9), 906-908. doi: 10.1016/S0002-8223(96)00245-3

9. Whitehair, K., Shanklin, C., \& Brannon, L. (2013). Written messages improve edible food waste behaviors in a university dining facility . Acad. Nutr. Diet, 113(4), 63-69. doi: 10.1016/j.jand.2012.09.015

10. Evans, D. (2018). Beyond the throwaway society: ordinary domestic practice and a sociological approach to household food waste. Sociology, 21(4), 429-440.

11. Li, X., Poon, C., \& Chung, S. (2016). Waste reduction and recycling strategies for the in-flight services in the airline industry. Resources, Conservation and Recycling, 37(1), 87-99. doi: doi.org/10.1016/j.resconrec.2016.03.023

12. Liu, G. (2017). Food losses and food waste in China: a first estimate. OECD Food, Agriculture and Fisheries Papers, 66(7), 47-55.

13. Tsili staloho rozvytku 2016-2030. (2017). Retrieved October 9, 2019, from http://www.un.org.ua/ua/tsilirozvytku-tysiacholittia/tsili-staloho-rozvytkuundefined.

Received 15 October 2019

Approved 29 October 2019

Цитування згідно ДСТУ 8302:2015

Available in Internet 26.12.2019

Седікова I.O., Дьяченко Ю.В. Шляхи зниження продовольчих втрат та харчових відходів // Економіка харчової промисловості. 2019. Т.11, вип. 4. С. 98-104. doi: 10.15673/fie.v11i4.1552

Cite as APA style citation

Sedikova, I., \& Diachenko, Yu. (2019). Ways to reduce food losses and food waste. Food Industry Economics, 11(4), 98-104. doi: 10.15673/fie.v11i4.1552 